\title{
FIRST STAGES OF THE POST-FIRE NATURAL REGENERATION OF VEGETATION IN THE VENTANILLA WETLANDS (LIMA-PERU)
}

\section{PRIMEROS ESTADIOS EN LA REGENERACIÓN NATURAL DE LA VEGETACIÓN POST-INCENDIO EN LOS HUMEDALES DE VENTANILLA (LIMA-PERÚ)}

\author{
Héctor Aponte ${ }^{1,2}$, Dámaso W. Ramírez ${ }^{2,3}$ y Raúl Vargas ${ }^{3}$
}

\begin{abstract}
In the wetlands of Peru's central coast, fires are a recurrent problem. Little is known concerning their impact on vegetation and the recovery strategies adopted by that vegetation in response to such events. The goal of this study is to provide information regarding changes in vegetation cover, density, growth and plant species diversity during the first 155 days after a fire that occurred at the Ventanilla Wetlands Regional Conservation Area (RCA). In order to evaluate the area, 51 plots, each measuring $1 \mathrm{~m}^{2}$, were established. In these, the following information was recorded: a) Number of stems that survived the fire, divided by species; b) The length of new shoots, divided by species; c) The phenological stage of each stem; and d) Plant cover, obtained via visual estimation. Schoenoplectus americanus (bulrush) was the fastest to recover, followed by Distichlis spicata-Sporobolus virginicus (saltgrass). The only stems found to have survived the fire were those of $S$. americanus, and these began to die from day 45 onwards. Sarcocornia neei, Typha domingensis and Bolboeschoenus maritimus appeared after the event. Throughout the period of the study, the only species to flower was $S$. americanus, which began to flower from day 31. The Shannon Wiener and Simpson index values show that alpha diversity seems to have reached its highest value in the evaluated time and begins to decrease. Two important post-fire stages were identified for $S$. americanus (bulrush): a) The survival stage; and b) The growth stage. $S$. americanus has demonstrated a great ability to recover in the first stages following this type of anthropogenic impact, achieving an average cover of $82 \%$ and representing $81 \%$ of the total abundance of stems during the first 155 days of evaluation.
\end{abstract}

Key words: Fires, succession, regeneration, resilience, wetlands.

\section{Resumen}

Los incendios en los humedales de la costa central del Perú son recurrentes. Poco se conoce de sus impactos sobre la vegetación y de las estrategias de recuperación de la misma frente a estos eventos. El objetivo del presente estudio es el de dar a conocer los cambios en la cobertura, densidad, crecimiento y diversidad de especies vegetales durante los primeros 155 días posteriores a un incendio ocurrido en los Humedales de Ventanilla (sector Área de Conservación Regional, ACR). Para evaluar el área, se establecieron 51 parcelas de $1 \mathrm{~m}^{2}$. En ellas se anotó a) el número de tallos que sobrevivió al incendio por especie b) la longitud de los nuevos rebrotes por especie, c) el estadio fenológico de cada tallo, y d) la cobertura vegetal obtenida mediante estimación visual. La recuperación de las especies dominantes ante los efectos del fuego fue diferencial. Schoenoplectus americanus "junco" se recuperó con mayor rapidez seguido de Distichlis spicata-Sporobolus virginicus "grama salada". Solo $S$. americanus presentó tallos que sobrevivieron al incendio, los cuales fueron muriendo a partir del día 45. Sarcocornia neei, Typha domingensis y Bolboeschoenus maritimus aparecieron posteriormente en la sucesión. A lo largo del estudio, la única especie que entró en floración fue $S$. americanus, la cual se encontró en floración a partir del día 31. Los valores del índice de Shannon Wiener y Simpson muestran que la diversidad alfa parece haber alcanzado su valor más alto en el tiempo evaluado y empieza a decrecer. Se identificaron dos estadios importantes posteriores al incendio para $S$. americanus "junco": a) el estadio sobreviviente, y b) el estadio de crecimiento. S. americanus ha mostrado tener una gran capacidad para recuperarse en los primeros estadios ante este tipo de impacto antrópico, alcanzando una cobertura promedio de $82 \%$ y representando el $81 \%$ de la abundancia de tallos totales en los primeros 155 días de evaluación.

Palabras clave: Humedales, incendios, resiliencia, sucesión, regeneración. 


\section{Introduction.}

The burning of vegetation is a widespread practice in the tropics, where it is mainly used as part of agricultural activities. This practice enables the removal of vegetation cover, the control of pests and weeds, and the adding of nutrients to the soil (Hernández-Valencia \& López-Hernández, 2002). In South American wetlands, this episodes of fire are also common, and (with grazing) is considered one of the anthropogenic impacts that shape and determine the ecosystem evolution and dynamics (Batzer \& Sharitz 2006, Keddy 2010). Globally and compared to terrestrial ecosystems, wetlands are poorly studied in relation the effects of fire and functioning of these environments (Smith et al., 2001; Kotze, 2013; Bixby et al., 2015). In these ecosystems the effects of fire are complex and depend on certain characteristics such as size, severity and frequency of burning, related to internal factors such as hydrology and geomorphology of the wetland (Bixby et al., 2015; Watts et al., 2015). In South American wetlands, this episodes of fire are also common, and (with grazing) is considered one of the anthropogenic impacts that shape and determine the ecosystem evolution and dynamics (Batzer \& Sharitz 2006, Keddy, 2010).

In the wetlands of Peru's central coast, fires are also caused on a regular basis as the result of human activity (Aponte et al., 2015). In some cases, anthropogenic burning is used to control bulrush
(Schoenoplectus americanus), enabling the plant, according to those who extract this fiber, to grow in a way that keeps the tissue free of pests (Aponte et al., 2014). Other fires are caused by people burning waste or by those with an interest in acquiring the land occupied by wetlands (Aponte \& Ramirez, 2014).

The effects of fire on biological diversity can be neutral, positive or negative, and a range of effects have been reported on the planet's ecosystems (Vogl, 1973; Koenen \& Koenen, 2000; Bond \& Keeley, 2005; Salvia et al., 2012; Ukmar et al., 2007). In the case of the coastal wetlands of Peru, little is known about the effect of fire on these ecosystems. Even though there have been reports of possible over dominance of some species as a result of fires (Aponte \& Ramírez, 2011), it has remained unclear as to whether these ecosystems are resilient in terms of their ability to counter the effects of such events (Aponte $e t$ al., 2015). Studying the natural post-fire regeneration of these environments allows us to gain some insight into the ability of these ecosystems to recover from such impact.

The goal of this study is to offer a detailed report on changes in the cover, density, growth and diversity of species during the first 155 days after a fire occurred in the Ventanilla Wetlands Regional Conservation Area (RCA).

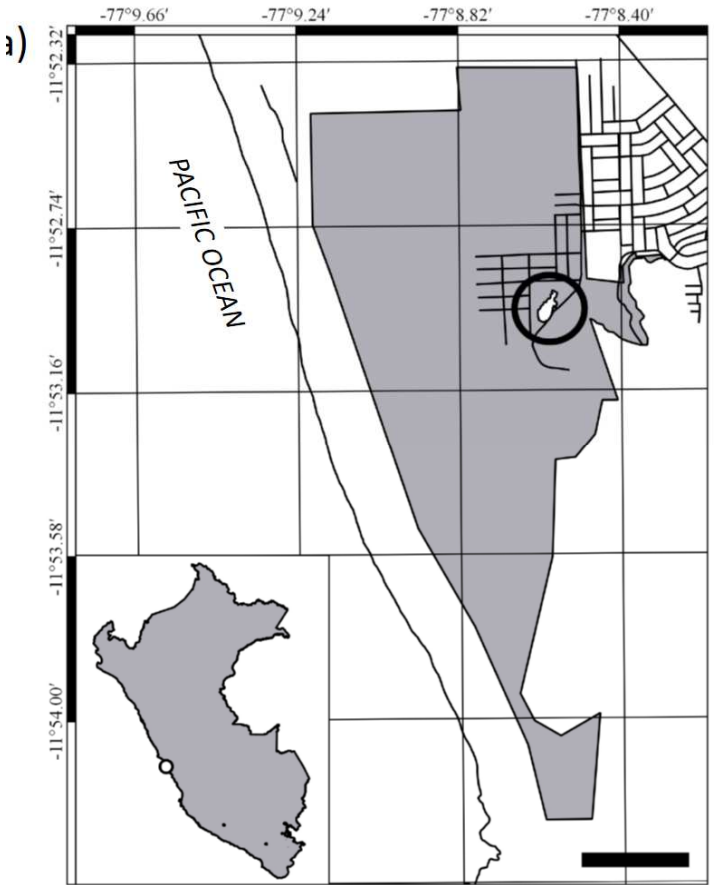

b)

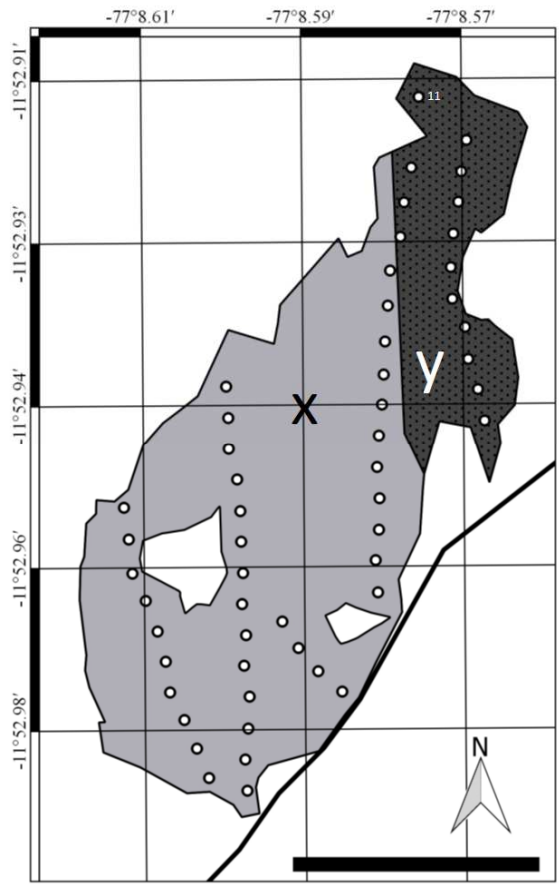

Figure 1. Study area. a) Map of the study area in Perú and detail of the Ventanilla Wetlands RCA; a circle marks the zone affected by fire; Scale 500 meters. b) Detail of the fire-affected zone, showing the area of reed beds (y), grasslands (x), and the plot 11 . Scale 50 meters. 
Study Area.

The Ventanilla Wetlands Regional Conservation Area (RCA) is located in the Constitutional Province

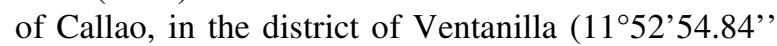
$\mathrm{S}-77^{\circ} 08^{\prime} 35.25^{\prime}$ ' W, Figure 1a). It is bordered to the south by low hills, to the east by areas of urban sprawl, and to the west by the coastline at Playa Costa Azul (Aponte \& Ramirez, 2014). The fire took place in the eastern sector of the wetlands on March $28^{\text {th }}$ 2014 (Figure 1b). The typical plant communities of the area are: rushes dominated by Schoenoplectus americanus (bulrush); grasslands dominated by Distichlis spicata and Sporobolus virginicus (saltgrass); reed beds mostly dominated by Schoenoplectus californicus (California bulrush, or "totora" in Peru); and areas of Salicornia, dominated by Sarcocornia neei (glasswort).

At the time the fire occurred (March 28 $8^{\text {th }}$ 2014), the wetland flora was being monitored (Aponte \& Ramirez, 2014), so we were able to assess the affected zone. Because of this anthropogenic disturbance, an area of 0.7 hectares (less than $0.3 \%$ of the total area of the RCA) was lost. The most abundant species, and the species most affected by the fire, were Schoenoplectus americanus (bulrush), Typha domingensis (Southern cattail), Bolboschoenus maritimus, Sporobolus virginicus and Distichlis spicata (saltgrass), all of which formed part of the grasslands and reed beds. The soil of the reed beds consisted mostly of the decomposing stems of the species themselves ( $S$. americanus and $T$. domingensis), of a principally organic and waterlogged nature, while the soil of the grasslands was mostly sandy or sandy and claylike in nature, and partially waterlogged.

With the goal to determine the burn severity (following Keeley, 2009) in the affected wetland area, we follow the study of Salvia et al. (2012) who identify three fire severity classes for coastal wetland: low severity, medium severity, and high severity. These classes are characterized by a remnant vegetation cover and a loss of matter organic. Considering the damage made on this area (the loss was more than the $95 \%$ of vegetation above soil), we can classify this episode like a high severity class.

\section{Methods.}

\section{Sampling.}

There were nine evaluations on days $3,17,31,45$, $59,73,87,122$ and 155 after the fire. The sampling in the affected zone was carried out using 51 plots, each of which measured $1 \mathrm{~m}^{2}$, distributed throughout the length of four transects covering the affected area and all the affected plant communities. The fire damage was similar in all plots evaluated (high severity). These were arranged in a stratified design, allowing evaluation of the entire reed bed and grassland areas; the distance between the plots was 5 meters (except plot 11 , which was placed at 10 meters from other plots, on a reed bed equally affected, just to cover the affected area, see Figure 1b for plot distribution).

It was measured in each plot: a) The number of stems that survived the fire, divided by species; $b$ ) The length of new shoots, divided by species; c) The phenological stage of each stem; and d) plant cover, obtained via visual estimation (a widely used method for assessing dominance, succession, and monitoring vegetation, including wetland vegetation cover; Hatton et al., 1986, Floy and Anderson 1987, Dethier et al., 1993, Godínez-Alvarez et al., 2009, Friedman et al. 2011, Rochefort et al. 2013). Where cover was greater than $80 \%$, the counting and measuring of individual specimens proved more difficult: for this reason, when a parcel exceeded this cover only the variables in one quarter of the parcel were recorded, multiplied by four to obtain the number of stems for the entire parcel (this was done from day 73 (plots 5 and 7), day 122 (plots 1, 4 and 6) or day 155 (2, 8 and 10 ) as needed). In order to reduce sampling bias by the observer, the field evaluators (authors) were the same in all the monitoring activities, which improves the evaluation considerably (Godínez-Alvarez et al 2009, Friedman et al 2011). Because of the difficulty in differentiating between Sporobolus virginicus and Distichlis spicata in the form of regrowth, these species were both treated as saltgrass.

Analysis of data.

The post-fire recovery of each species was quantified in two ways: a) The first way consisted of the sum of the number of stems per species; and b) The second way consisted of the sum of the length of all the stems per species, and this parameter was known as longitudinal stem production (LSP). Graphs were produced for both variables, which were transformed logarithmically to better appreciate the details concerning less abundant or shorter species.

In order to analyze the length reached by the stems of each species throughout the entire evaluation period, box plots were produced using PAST $2.17 \mathrm{c}$ software (Hammer et al., 2001).

With data on abundance and richness of all plots, the Shannon Wiener diversity index (logarithm to the base e) and Simpson's dominance index were calculated for the affected area. This calculation was done with PAST software using the values for the numbers of stems per species in each evaluation. In order to understand the diversity tendency over time, regressions were performed using the Curve finder tool (all model families except polynomial) in Curve Expert program (Hyams, 2010); the best fit was chosen considering the smaller standard error (se) and highest correlation coefficient (r).

From the vegetation cover of the different plots, maps were built up in order to observe the recovery process over time. These maps were constructed by interpolating the vegetation cover using the Kriging 
a)

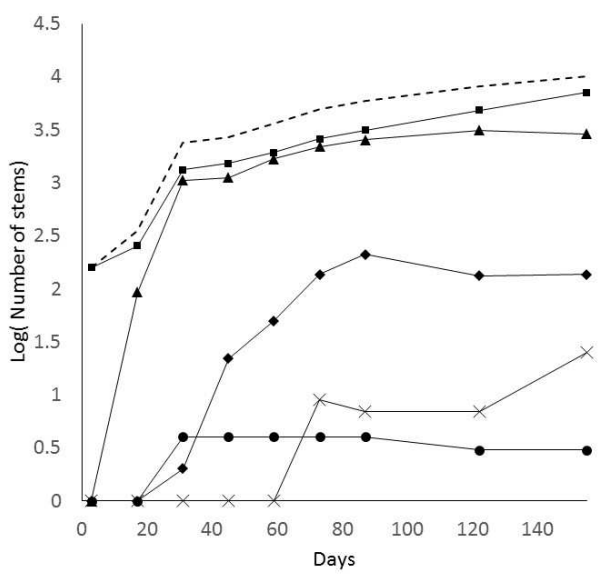

b)

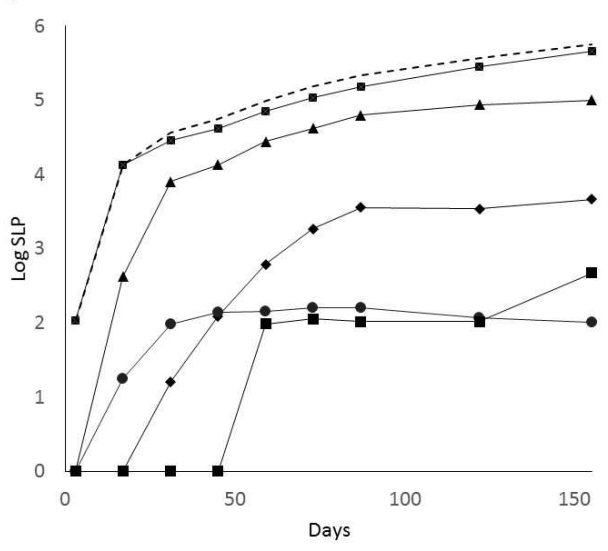

Figure 2. Changes in abundance over time expressed as the logarithm of the number of stems (a) and Stem Length Production (SLP) (b); where these values were 0, 0 was shown. The dotted line shows the sum of all species. $\boldsymbol{\nabla}=S$. americanus; $\boldsymbol{\Delta}=D$. spicataS. virginus (saltgrass); $\diamond=$ Sarcocornia neei; $\mathbf{O}=$ Typha domingensis; $\mathrm{X}=$ Bolboschoenus maritimus.

technique (Oliver \& Webster, 1990) using the ordinary spherical model. This process was carried out using Q.GIS 2.14 and SAGA GIS 2.2, allowing to produce graphs of the respective maps.

\section{Results.}

The number of stems and the LSP over time are shown in Figure 2. Schoenoplectus americanus (bulrush) was the species which recovered most rapidly during the evaluation period. This species had the highest abundance (69\% of the stems) and growth ( $81 \%$ of LSP) over the 155 days, followed by saltgrass ( $28 \%$ and $18 \%$, respectively); the other did not exceed $2 \%$ for both variables.

The length of the stems for all species, except for Typha domingensis, increased progressively over the evaluation period (Figure 3). Temporal analysis allow us to show that in the fastest growing species ( $S$. americanus, Distichlis spicata-Sporobolus virginicus, and $S$. neei) stem length growth occurred at the same time that new shoots were propagated. The average length after 155 days was $63.78 \mathrm{~cm}$ for $S$. americanus, $34.61 \mathrm{~cm}$ for D. spicata-S. virginus (saltgrass), 34.07 $\mathrm{cm}$ for $S$. neei, $33.33 \mathrm{~cm}$ for $T$. dominguensis and $18.72 \mathrm{~cm}$ for $B$. maritimus.

Of all species affected by the fire, only some of the $S$. americanus survived the burning, while the other species did not exhibit surviving stems. On days 3, 17 and 31 , a total of 19,753 and 850 surviving bulrush stems were counted; from day 45 , this amount was progressively reduced (Figure 4). From this moment, productivity was maintained with the new shoots generated by rhizomes (asexual reproduction), the majority of which belonged to $S$. americanus.
Throughout the study, the only species to flower was $S$. americanus, which was found to flower from day 31 ( 6 of the bulrush stems were flowering). The number of stems in flower continued to increase, although the proportion of these relative to the total number of stems continued to decline. By day 155 , 940 of the stems were flowering (13.3\% of the total) (Figure 5).

Cover values were highest in the zone where $S$. americanus was predominant, reaching by day 155 an average of $82 \%$ cover, and with a maximum of $100 \%$ in three plots and $90 \%$ in three others (Figure 6). The grass zone had an average cover of $34 \%$ by day 155 . Two plots of grasses registered $0 \%$ cover during the evaluation.

The Shannon Wiener index values show that alpha diversity grows according to an exponential model ( $\left.\mathrm{y}=\mathrm{a}\left(\mathrm{b}-\mathrm{e}^{-\mathrm{cx}}\right) ; \mathrm{a}=1.02 ; \mathrm{b}=7.47 ; \mathrm{c}=9.76 ; \mathrm{se}=0.05 ; \mathrm{r}=0.99\right)$. Simpson's Dominance values show that dominance decreases according to a rational function $\left(\mathrm{y}=(\mathrm{a}+\mathrm{bx}) /\left(1+\mathrm{cx}+\mathrm{dx}^{2}\right) ; \mathrm{a}=1.31 ; \mathrm{b}=4.86 ; \mathrm{c}=1.56 ; \mathrm{d}=-\right.$ 3.95; se=0.01; r=0.99) (Figure 7). In both cases, diversity seems to have reached its highest value.

\section{Discussion.}

The results show rapid recovery of vegetation cover after the fire, particularly in the case of $S$. americanus (bulrush). The principal means of reproduction observed in this species were asexual, through rhizomes. Therefore, the production of clones from bud growth is the main tool for the recovery of the cover after fires. This characteristic allows us to suggest that vegetation dominated by $S$. americanus (bulrushes) is resistent to fire. This characteristic of 
the vegetation is what gives the Ventanilla wetlands the ability to respond to these events, despite being considered a fragile ecosystem (Moya et al., 2005; Pronaturaleza, 2010; Tavareset al., 2012). This also reflects the similarities seen in the recovery of this type of ecosystem and forest ecosystems, where recovery through asexual reproduction plays a key role in the early stages of post fire recovery (Hoffmann, 1998; Kennard et al., 2002). Considering the results of this study, the fire doesn't seem to affect the dominance of autochthonous species; phenomenon reported for other Neotropical wetlands (Rocha et al, 2015).
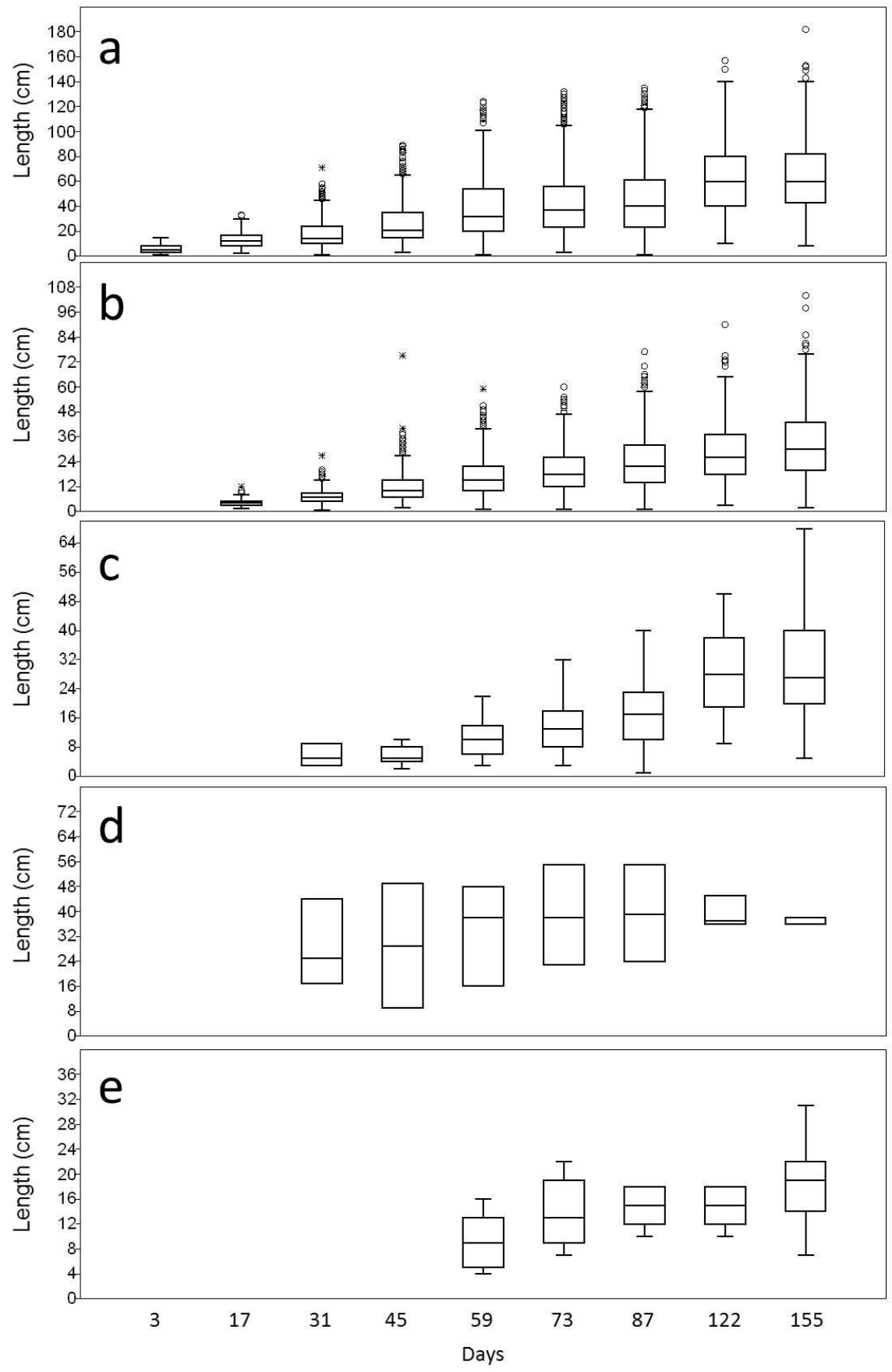

Figure 3. Length of the stems during the study period: a) Schoenoplectus americanus (bulrush); b) D. spicata-S. virginus (saltgrass); c) Sarcocornia neei (glasswort); d) Typha domingensis (Californian bulrush, or "totora" in Peru); and e) Bolboschoenus maritimus. Oand * represent outliers. 


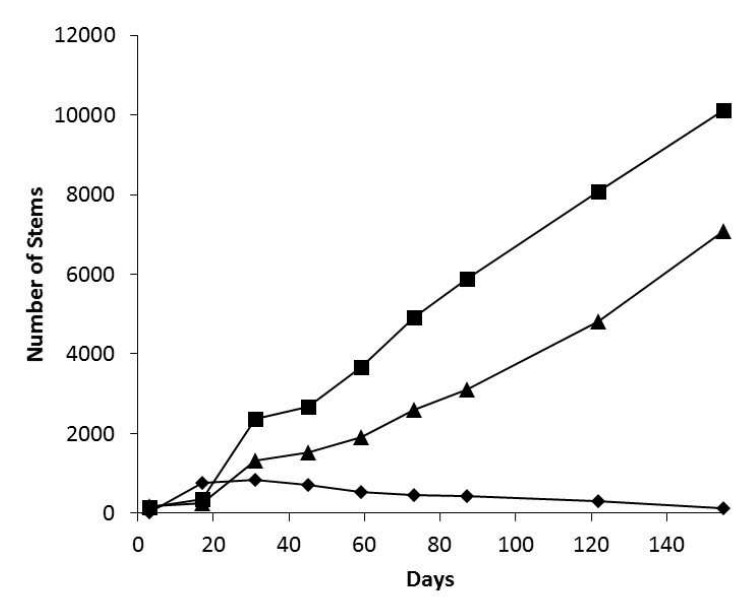

Figure 4. Growth of stems throughout the evaluation period: $\boldsymbol{\nabla}=$ Shoots in all species; $\boldsymbol{\Delta}=$ Bulrush shoots; $\bullet$ Surviving stems.

We can see, therefore, that bulrush is a species that recovers quickly over a short period (approximately 5 months) after fires. The fact that a considerable number of surviving stems (850) were found could be related to the degree of fire intensity, but it also reveals the potential for this species to remain functional despite being affected. This ability to recover may also be related to the type of substratum in which it lives. The large amount of organic matter and water of which wetland soils are composed may have favored its growth; a response which has been documented under laboratory conditions (Aponte, 2009). This great capacity for growth and regeneration, characteristic of the species, is probably the best explanation of the spatial differences of recovery in the affected area at the end of the study (Figure 6).

In this study, the reed beds were found to recover rapidly after the fire. Given the recurrent nature of fires in the wetland areas of Peru's central coast and given the bulrush responsiveness, controlled fires could be considered suitable activities for use as part of the management of bulrushes. However, it should also be remembered that fauna may be affected by fire (Knapp et al., 2009), and therefore it is essential that further complementary studies be undertaken in order to evaluate this scenario over a longer period.

The diversity obtained by day 155 (Simpson's Dominance Index) is comparable to the diversity of other wetlands on Peru's central coast. This index varies between 0.36 and 1 for the grasslands and reed beds of wetlands such as Puerto Viejo, Medio Mundo, Laguna el Paraíso and Humedal Santa Rosa (Aponte \& Ramírez, 2011). The value on day 155 was 0.56 ; this value lies within the known diversity range for coastal wetlands. The results of the present study show that diversity seems to have reached its highest value; if this trend continues, alpha diversity could be maintained (if species succeed in establishing their populations) or decrease (if grasses and rushes begin to occupy available space by displacing other species). Subsequent studies will enable us to test this hypothesis.

From what was observed over the 155 days, we can identify two initial stages of post-fire succession in S. americanus:

a) Survival stage: This is composed of what happened during the first 30 days after the fire, when the productivity of the affected area was maintained mostly due to the surviving stems. In this study, this stage was characterized by the survival of bulrush stems, which despite of having been burned continued to grow. In this study, dominance is high (the only species to survive in this study was the bulrush, $S$. americanus.

b) Growth stage: This is composed of what occurred after the survival stage, a period during which the biomass of the area is regenerated through rhizome shoots. During this stage, the shoots replace the surviving stems and biological diversity reaches its maximum value. In this study, the sequence among species for the appearance of shoots was as follows (from first to last): Schoenoplectus americanus, Distichis spicataSporobolus virginicus, Sarconornia neei; Typha domingensis and Bolboschoenus marítimus.

Complementary studies in similar ecosystems will make it possible to establish whether or not this pattern is repeated during subsequent post-fire stages. The present study describes for the first time the first stages of a natural regeneration after fire in wetlands of the Peruvian coast.

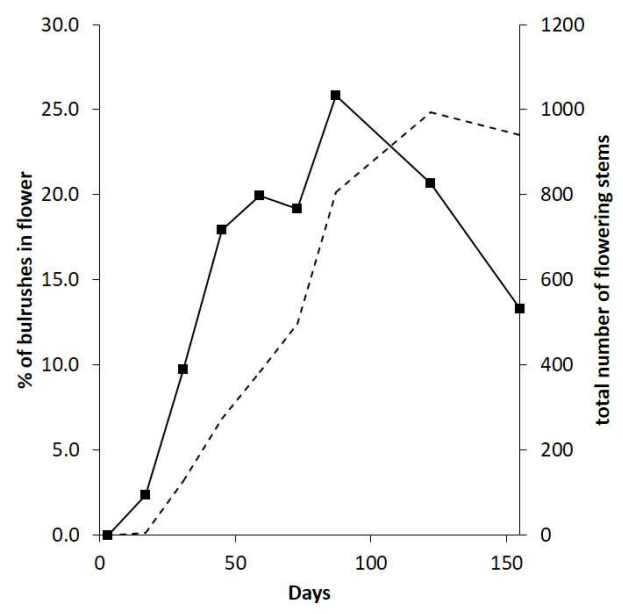

Figure 5. Flowering of bulrushes throughout the evaluation period. $\mathbf{\square}=\%$ of bulrushes in flower; - -= total number of flowering stems. 

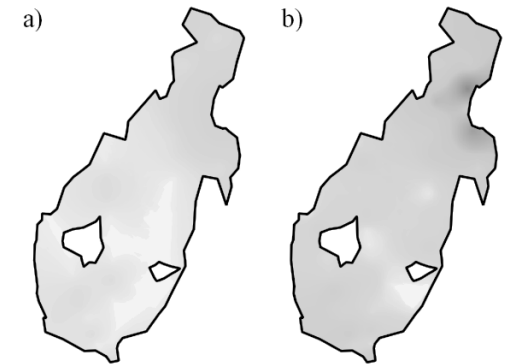

e)

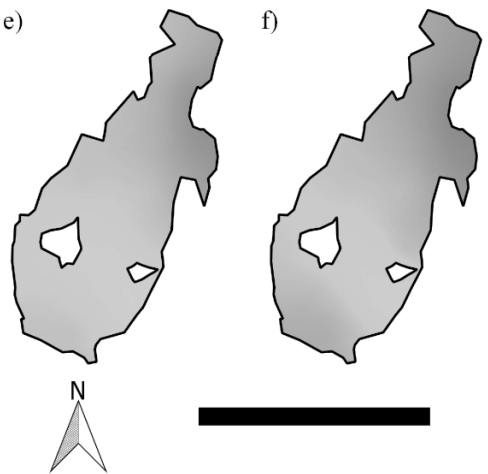

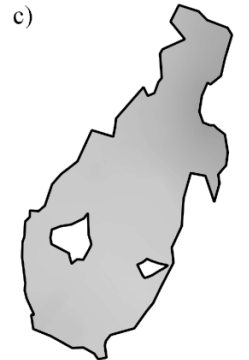

g)

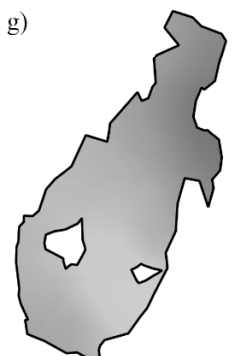

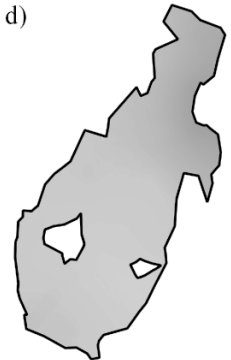

h)
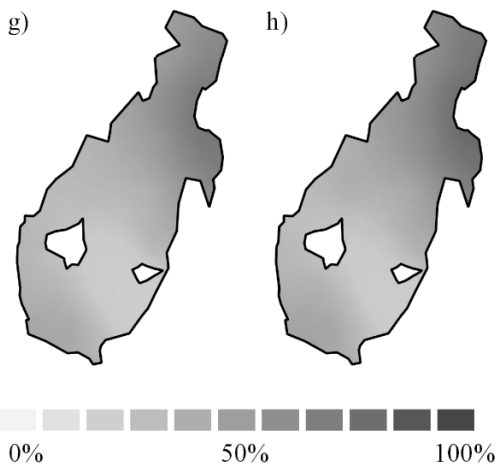

Figure 6. : Vegetation cover in the study area at: a)17; b)31; c)45; d)59; e)73; f)87; g)122 and h) 155 days .

\section{Conclusions.}

Two important post-fire stages have been identified for Schoenoplectus americanus: a) The survival stage; and b) The growth stage. In both cases, it is asexual reproduction which enables recovery of the affected area. Schoenoplectus americanus has demonstrated an ability to recover rapidly from this type of anthropogenic impact, reaching high levels of cover $(82 \%)$, abundance $(69 \%)$ and growth $(81 \%)$ by day 155 of the evaluation. Grasses (D. spicataS.virginicus) were the second group to recover $(34 \%$ cover). These results demonstrate the potential of these ecosystems for recovery after fire and the differential growth of species after disturbance by burning.

\section{Acknowledgments.}

We are grateful to the ACR Humedales de Ventanilla managers and the Callao Regional Government for their support for sampling. We also thank the reviewers of this manuscript for their valuable suggestions.

\section{References.}

Aponte H. 2009. El junco: clasificación, biología y gestión. Científica.6 (1): 38-45.

Aponte H., Pérez-Irigoyen P. \& Armesto M. 2014. Notas sobre el uso y mercado de Schoenoplectus americanus 'junco' en la costa central del Perú: Implicancias para su manejo y conservación. Científica. 11(3): 218-229.
Aponte H. \& Ramírez W. 2011. Los Humedales de La Costa central del Perú: Comunidades Vegetales y Conservación. Revista Ecología Aplicada. 10(1): 31-39.

Aponte H. \& Ramirez D.W. 2014. Riqueza florística y estado de conservación del Área de Conservación Regional Humedales de Ventanilla (Callao, Perú). Biologist (Lima). 12(2): 270-282.

Aponte H., Ramírez D., Lértora G., Vargas R., Gil F., Carazas N. \& Liviac R. 2015. Incendios en los Humedales de la Costa Central del Perú: Una amenaza frecuente. Científica. 12(1): 70-81.

Bixby R. J., Cooper S. D., Gresswell R. E., Brown L. E., Dahm C. N., \& Dwire K. A. 2015. Fire effects on aquatic ecosystems: An assessment of the current state of the science. Freshwater Science. 34(4), 1340-1350.

Bond W.J. \& Keeley J.E. 2005. Fire as a global 'herbivore': the ecology and evolution of flammable ecosystems. Trends in Ecology \& Evolution. 20: 387-394.

Dethier M.N., Graham E.S., Cohen S. \& Tear L.M., 1993. Visual versus random-point percent cover estimations: 'objective' is not always better. Marine Ecology Progress Series. 96, 93-100.

Floyd D.A. \& Anderson J.E., 1987. A comparison of three methods for estimating plant cover. Journal of Ecology. 75, 221-228.

Friedmann B., Pauli H., Gottfried M. \& Grabherr G. 2011. Suitability of methods for recording species numbers and cover in alpine long-term vegetation monitoring. Phytocoenologia. 41 (2): $143-149$.

Godínez-Alvarez H., Herrick J.E., Mattocks M., Toledo D., and Van Zee J. 2009. Comparison of three vegetation monitoring methods: their relative utility for ecological assessment and monitoring. Ecological indicators. 9 (5): $1001-1008$ 
Hatton T.J., West N.E., Johnson P.S., 1986. Relationships of the error associated with ocular estimation and actual total cover. Rangeland Ecology and Management. 39, 91-92.

Hammer $\varnothing$, Harper D.A.T. \& Rayan P.D. 2001. PAST: Paleontological statistics software package for education and data analysis. Palaeontologia Electronica. 4(1):1-9.

Hernández-Valencia I. \& López-Hernández D. 2002. Pérdida de nutrimentos por la quema de la vegetación en una sabana de Trachypogon. Revista de Biología Tropical.50: 1013-1019.

Hoffmann W.A. 1998. Post-burn reproduction of woody plants in a neotropical savanna: the relative importance of sexual and vegetative reproduction. Journal of Applied Ecology.35: 422-433.

Hyams D.G. 2010. Curve Expert software V. 1.4.

Keeley J. E. 2009. Fire intensity, fire severity and burn severity: a brief review and suggested usage. International Journal of Wildland Fire. 18(1), 116-126.

Kennard D.K., Gould K., Putz F.E., Fredericksen T.S. \& Morales F. 2002. Effect of disturbance intensity on regeneration mechanisms in a tropical dry forest. Forest Ecology and Management.162: 197-208.

Knapp E., Estes B. \& Skinner C. 2009. Ecological Effects of Prescribed Fire Season: A Literature Review and Synthesis for Managers.General Technical Repport PSW-GTR-224. Albany, CA: U.S. Department of Agriculture, Forest Service, Pacific Southwest Research Station, Estados Unidos.

Koenen M. \& Koenen S. 2000. Effect of fire on birds in Paramo habitat of Norther Ecuador. OrnitologíaNeotropical.11: 155-163.

Kotze D. C. 2013. The effects of fire on wetland structure and functioning. African Journal of Aquatic Science. $38(3), 237-247$.
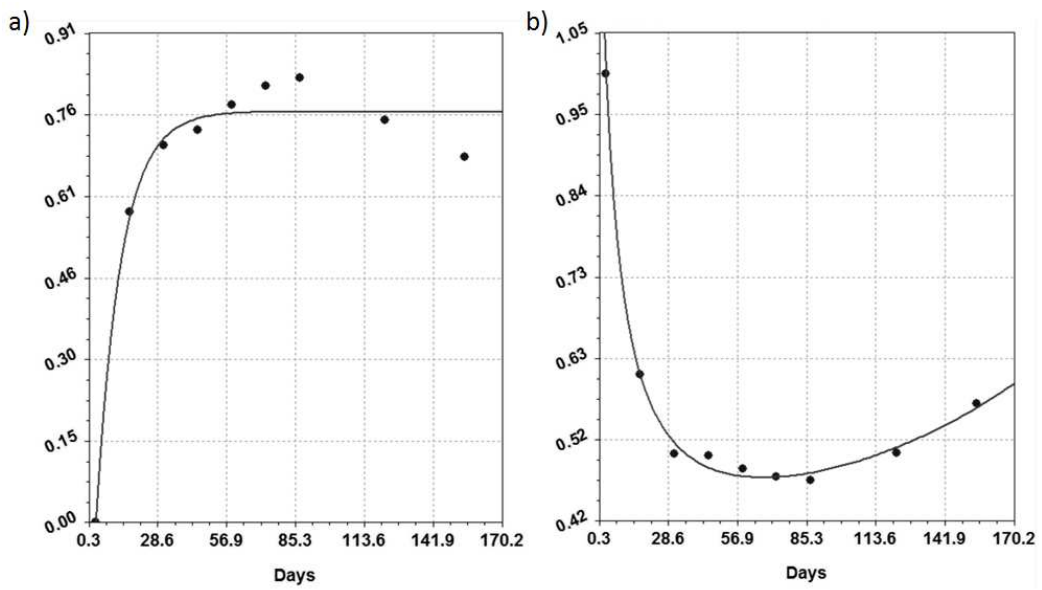

Figure 7. Shannon Wiener Index (a) and Simpson's Dominance Index (b) throughout the evaluation period.

\footnotetext{
${ }^{1}$ Facultad de Ciencias Biológicas y Veterinarias. Escuela de Biología Marina. Universidad Científica del Sur. Av. Antigua Carretera Panamericana Sur km 19 Villa El Salvador. - Lima 42, Perú. haponte@cientifica.edu.pe. ${ }^{2}$ Museo de Historia Natural, Universidad Nacional Mayor de San Marcos. Avenida Arenales 1256, Jesús María Lima. Apartado 14-0434, Lima 14, Perú.

3 Área de Biología. Coordinación de Cursos Básicos de Ciencias. Universidad Científica del Sur. Av. Antigua Carretera Panamericana Sur km 19 Villa El Salvador. - Lima 42, Perú.
} 